\title{
地山ガス抜について
}

\section{Gas Drainage in Mitsubishi Takashima Coal Mine}

\section{1. 緒言}

一般に炭鉱では採掘速度の増加および深部移行に伴い ガス発生量も増加するが，当所においても例外ではなく とくに当所では近接した累層を採掘するため最初に掘る 炭層へその炭層のみならず他の近接累層からのガスが， 集中的多量に湧出してきて，採掘作業を阻害するばかり でなく坑内深度の増加に伴いガスの湧出量も多くなり， これがため深部開発の計画樹立の上にも種々の制約を与 えてきた。

これが対策として風道の拡大ならびに主扇の増強によ り風量の増大を図るとともに，坑内ガス抜について昭和 36年当初より予備実験を開始して以来，基礎調查と実験 とを繰返し昭和36年12月より地山ガス抜を主体とするガ ス抜法を積極的に展開し，坑内外の誘導設備および坑外 ガス利用設備を完成し，その結果保安

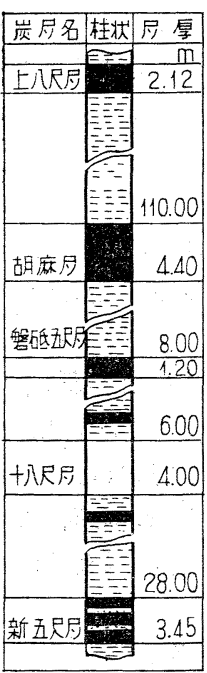

第 1 図

炭層柱状図
の確保と切羽の集約等による生産能率 の向上が期待できるようになり，坑内 全般の合理化，集約の上に有形無形の 利益をもたらし，コストの引下げにい ささか寄与している。

坑外に誘導したガスは昭和 39 年 9 月 当初より所内の発電所およびボイラー 用燃料さして利用中であり，月間約 3, 000 tの節炭を可能にしている。今後 さらにガスの有効利用としてガスター ビンによる発電も考究中である。

\section{2. 矿業所概況}

当所恃長崎市の西南海上 $14.5 \mathrm{~km}$, 囲周 $6.4 \mathrm{~km}$ ，面積 $0.95 \mathrm{~km}^{2}$ の高島に あり，明治末年に開坑し，現在鉣員は 2,600 人，年間出炭 150 万 $\mathrm{t}$ で産出炭は
正会員高 道 道 三 Michizo TAKAMICHI.
原料炭である。稼行可能な炭層は第 1 図に示す通り端島 夾炭層（層厚 150 200m) に 4 8 枚夾在され，上部 より上八尺層, 胡麻五尺層, 胡麻下三尺層, 磐砥五尺 層, 亀三尺層, 十八尺層, 新五尺層であり累計層厚は 14 16m に達する。傾斜は 25 30 で地層は数 $\mathrm{km}$ にわ たり安定している。

採炭法は片盤向長壁式採炭で切羽支保には鉄柱（水圧 鉄柱)，カッペを使用しいずれも総ばらしである。

採掘は最上層の胡麻層払（スライシング払）から始め られ追掛払として磐砥層払，十八尺層払の順であり集約 採炭の実をあげている。現在の稼行深度は海底下 540 $630 \mathrm{~m}$ である。

\section{3. ガ ス 状 況}

ガス涌出量の推移は第 1 表の通りで九州としては多い 方で昭和29年頃より採炭の主力が浅部に移行したのに伴 いガス湧出量は一時減少したが，昭和37年以降採掘区域 が再び深部に移行するに伴い急増した。

当所の石炭は非常にガスを通し易い空隙が多く，僅か の擾乱によつて生ずる微細な割目を通じて石炭中のガス が極めて容易に逸脱する傾问にある。

最初に採掘する一次払については, 切羽総湧出ガス量 は約 15 $25 \mathrm{~m}^{3} / \mathrm{min}$ でありその中，払跡よりの涌出ガス 量は約 $30 \%$ に相当する. $4 \sim 7 \mathrm{~m}^{3} / \mathrm{min}$ であり, 残りは切羽 内における涌出が大半で一部, 深沿層坑道よりの湧出で ある。

切羽の通気量は炭しんの飛散防止, 自然発火等の関係 より $1,000 \mathrm{~m}^{3} / \mathrm{min}$ 程度が限度であり，ガス抜なくしては 到底採掘し得ない状況である。また二次払のガス湧出量 は一次払の約 $1 / 4$, 三次払のそれは約 $1 / 10$ まで減少する。

以上のことよりガス抜の重点は一次払時のガス減少お よび深片盤の関連沿層掘進のガスを去勢することである が，従来より広く行なわれている払跡上盤穿孔ガス抜法

第1表 ガ ス 湧出量推移表

\begin{tabular}{|c|c|c|c|c|c|c|c|c|c|c|c|c|c|c|c|c|}
\hline & 昭26 & 27 & 28 & 29 & 30 & 31 & 32 & 33 & 34 & 35 & 36 & 37 & $38 / 9$ & $39 / 3$ & $39 / 9$ & $40 / 3$ \\
\hline $\begin{array}{l}\text { 出 } \begin{array}{l}\text { 岸 } 1,000 \mathrm{t} \\
\text { ガ } \\
\text { 不 } \\
\text { 量 }\end{array}\left\{\begin{array}{l}\mathrm{m}^{3} / \mathrm{min} \\
\mathrm{m}^{3} / \mathrm{t}\end{array}\right.\end{array}$ & $\begin{array}{r}374 \\
45.8 \\
64.4\end{array}$ & $\begin{array}{r}334 \\
(50.6) \\
50.8 \\
(66.0) \\
80.2\end{array}$ & $\begin{array}{r}374 \\
69.9 \\
69.4\end{array}$ & $\begin{array}{r}422 \\
48.4 \\
60.2\end{array}$ & $\begin{array}{r}449 \\
40.4 \\
47.3\end{array}$ & $\begin{array}{r}496 \\
42.3 \\
45.0\end{array}$ & $\begin{array}{r}536 \\
(45.7) \\
45.7 \\
(42.7) \\
44.8\end{array}$ & $\begin{array}{r}430 \\
(38.4) \\
38.6 \\
(37.0) \\
47.2\end{array}$ & $\begin{array}{r}530 \\
40.0 \\
39.7\end{array}$ & $\begin{array}{r}731 \\
36.9 \\
26.5\end{array}$ & $\begin{array}{r}640 \\
37.2 \\
30.5\end{array}$ & $\begin{array}{r}783 \\
61.1 \\
42.3\end{array}$ & \begin{tabular}{r|}
$t / 9$ \\
63,000 \\
65.4 \\
44.6
\end{tabular} & $\begin{array}{r}t / \text { / } \\
95,500 \\
65.3 \\
29.5\end{array}$ & $\begin{array}{r}t / \text { /月 } \\
103,000 \\
67.1 \\
28.2\end{array}$ & $\begin{array}{r}t / \text { / } \\
106,500 \\
86.3 \\
36.2\end{array}$ \\
\hline
\end{tabular}

* 三菱釷業株式会社高島矿業所二子坑坑務課珢

（）内は長期ストのあつた月を除いた場合 
のみでは一次払時の上部に存在するメタンガスしか捕集 できず一次払の炭層自体に含まれるメタンガスおよび下 位炭層が近接しているためこれより遊離したメタンガス の切羽掠よび払跡を通つて気流中に混入するのを低下さ せる効果は不十分である。また払跡下盤穿孔は穿孔の困 難，その後のガス誘導上孔内の閉塞等により効果不十分 であつた。以上のことより当所としては盤下坑道より払 稼行前に各炭層を貫層させるいわゆる地山貫層穿孔力゙ス 抜を主体として，払跡上盤穿孔ガス拔を一次払の払跡に 対して補助的に実施している。

またこの地山貫層穿孔ガス拔実施以来, 従来往々にし てあつたガス突出事故をむ完全に防止しえている。

\section{4. 地山貫層穿孔ガス抜}

盤下掘進の進行に伴い約 $50 \mathrm{~m}$ 間隔にボーリング座 （加脊 $10 \mathrm{~m} \times 10 \mathrm{~m}$ ，奥行 $4.5 \mathrm{~m}$ ）を，また目貫掘進時に 際しては着炭前に目貫左右にボーリング座を設け，これ より各炭層を貫層させるボーリングを稼行すべき払全面 に亘るように行ない，払拉よび掘進に先立つてガスを誘 導する。

またこの際目貫左右座よりの穿孔の中，各座より 3 本 づつ先進方向に穿孔して以後の目貫掘進の着炭時のガス 突出予防㧍よびガスの低減を図つている。

なお一次払の深準備沿層, すなわち最上位層の沿層掘 進に際しては，さらに炭層中にボーリング座を設け，こ れょり沿層先進方向及び炭層地山に扇形に穿孔を行な い，掘進時におけるガスを低減せしめ，併せてガス突出 の危害防止を図っており，盤下よりの地山貫層穿孔法と とも第 2 図のような規格のもとに穿孔飞ており，掘進 は必ず $5 \mathrm{~m}$ 以上のカバーロックを厳守するようにしてい る。

以上のガス抜個所はすべて地山区域で実施中であり， 穿孔は孔径 $65 \sim 115 \mathrm{~mm}$, 孔長平均 $60 \mathrm{~m}$ で穿孔終了都度 3 in $\times 2.75 \mathrm{~m}$ （海底炭坑のため パイプ 類の腐食多くこれ ら不良パイプを転用）のガイドパイプを挿入 し周囲をセメントで固結後既設のガス抜パイ プに接続してガスを誘導する。その打合要領 は第3 図に示す。

穿孔機は NGPIV 6 型及びヤマト DY. 102 型を使用（NG5 台，DY3 台)している が，器械の送り，回転及びロッドの着脱をり ンマン遠方操作方式仁改良莸加えて作業人員 1 台当り 2 人制として, 月間約 $3,000 \mathrm{~m}$ 穿孔 している。特別の場合を除き湿式であり，能 率は約 $15 \mathrm{~m} /$ 方である。

第 4 図注地山貫層穿孔ガス拔における 1 座 当りのガス涌出量とガス拔開始からの日数と
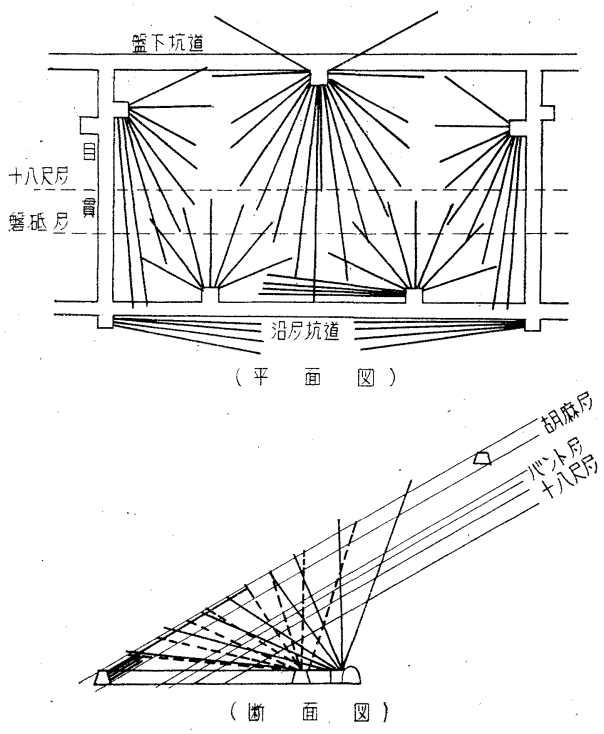

第 2 図地山貫層穿孔ガス抜規格図

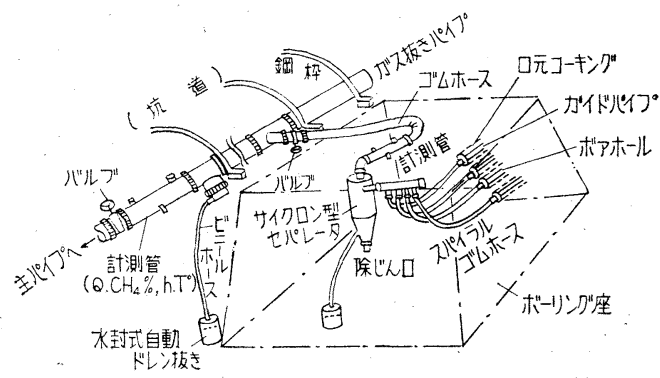

第3 図 ガス拨孔打合要領図

の関係を示す。

この図から地山貫層ガス抜の誘導特性として誘導ガス 量は予定孔数の穿孔終了時の吸引当初が多く以後漸減し 一次払近接時において再び増加の傾向を示し，一次払次 いで二次払の通過により孔の閉塞, 亀裂の発生等により ガス誘導量，濃度ともに減少して廃棄しているが平均寿

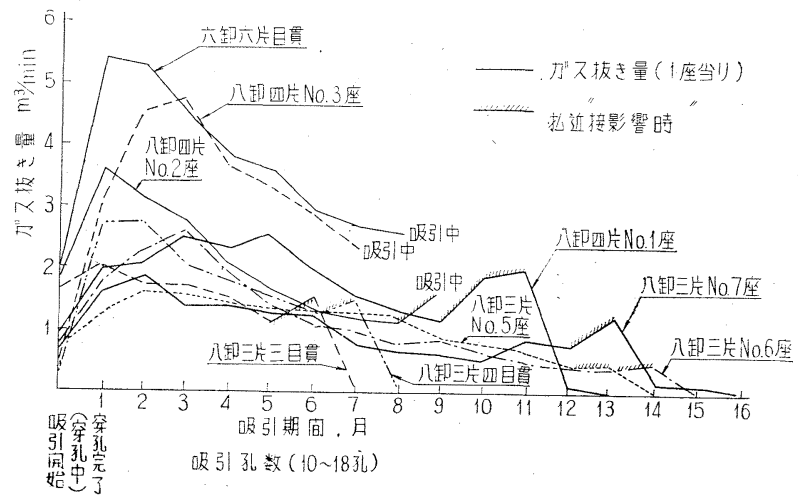

第4 図地山貫層がス抜座におけるガス誘導量推移 
第2表 ガ ス抜推移表

\begin{tabular}{|c|c|c|c|c|c|c|c|c|}
\hline \multirow{2}{*}{ 年月 } & \multirow{2}{*}{$\begin{array}{l}\text { ガス抜量 } \\
\mathrm{m}^{3} / \mathrm{min}\end{array}$} & \multicolumn{3}{|c|}{ ガス抜量内訳 } & \multirow{2}{*}{$\begin{array}{l}\text { 排気ガス量 } \\
\mathrm{m}^{3} / \mathrm{min}\end{array}$} & \multirow{2}{*}{$\begin{array}{l}\text { 総ガス量 } \\
\mathrm{m}^{3} / \mathrm{min}\end{array}$} & \multirow{2}{*}{$\begin{array}{c}\text { ガス抜率 } \\
\%\end{array}$} & \multirow{2}{*}{ 出 $t^{\frac{\omega}{W}}$} \\
\hline & & 地山 & 払跡 & 他 & & & & \\
\hline & 37 & 6.5 & 3.3 & & 2 & 60.12 & 16.0 & 94,000 \\
\hline & & & 3. & 0.57 & & & & \\
\hline & & 0 & 2.1 & & & & 30 & 72,400 \\
\hline 5 & & 1 & 2. 1 & b. & & & 36. & 93,000 \\
\hline 6 & & & 2.8 & 5. & & & 35 & 100,200 \\
\hline 7 & 2 & 1 & 2.45 & 6. & 6 & & 37 & 111,000 \\
\hline 8 & & & 0.9 & 5. & & & 36 & 90,500 \\
\hline 9 & & 1 & 1.4 & 4. & 44 & & 33 & 103,000 \\
\hline 10 & & & 5.8 & 6. & 47 & & 37. & 113,500 \\
\hline 11 & 36 & & 9.2 & & & & & 107,000 \\
\hline 12 & 31.97 & & 7.31 & 7. & & 79 & 40.0 & 117,000 \\
\hline 40.1 & & & 2.01 & & & & & 97,000 \\
\hline 2 & 30.13 & & 7.10 & 5. & 56 & 86 & 34.7 & 98,000 \\
\hline 3 & 29.90 & 18.56 & 3.51 & 7.83 & 56.40 & 86.30 & 34.6 & 106,500 \\
\hline
\end{tabular}

注） 39 年 7 月までガス抜は排気風道にて放流

第 3 表 地山穿孔ガス抜実績

(昭40.3末)

\begin{tabular}{|c|c|c|c|c|}
\hline 項 目 & 区 域 & 六 卸 & 八 卸 & 計 \\
\hline 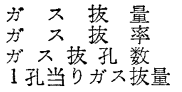 & $\begin{array}{c}\mathrm{m}^{3} / \mathrm{min} \\
\% \\
\mathrm{~m}^{3} / \mathrm{min}\end{array}$ & $\begin{array}{l}5.08 \\
40.1 \\
69 \\
0.07\end{array}$ & $\begin{array}{l}13.48 \\
49.6 \\
97 \\
0.14\end{array}$ & $\begin{array}{c}18.15 \\
46.7 \\
166 \\
0.11\end{array}$ \\
\hline
\end{tabular}

命としては約 1 年間である。また払採掘前短期間にガス を誘導したガス抜座については，まだガス誘導中でも払 通過により孔が閉塞し，または亀裂等よりガス誘導量が 極端に低下し廃暂せざるをえないといらことからガス抜 開始時期は少なくとも 1 年前より準備する必要がある。

1 座当りの総ガス誘導量は $600,000 \sim 800,000 \mathrm{~m}^{3}$ (吸 引孔数 $12 \sim 14$ 孔）であり 1 孔当り期間中平均のガス誘 導量は $0.1 \mathrm{~m}^{3} / \mathrm{min} /$ 孔である。

この地山穿孔ガス拔により，ガス圧，ガス量ともに減 少し掘進および採掘払のガス低減はもとよりガス突出の 危害も完全に避けらるようになつた。

第 2 及び第 3 表に最近のガス誘導状況抒よび地山ガス 抜の実績を示す。この表からガス抜設備の充実とともに 着実にガス誘導量は増加を示してきている。

\section{5. 払跡上盤穿孔ガス抜法}

前述のように採掘払においてはガスの多い先行一次払 にて実施中であり，その方法は払肩坑道上り払跡に上盤 穿孔を行なつているが, 状況によつては払肩天盤にガス 抜坑道を設け，これより払跡江対し穿孔ガス抜を実施し ている。

\section{6. ガス誘導 法}

坑外設設置された $175 \mathrm{~kW} 1$ 台（水柱 $5,000 \mathrm{~mm}$, 風量 $100 \mathrm{Nm}^{3} / \mathrm{min}$ ) にて吸引し, $100 \mathrm{~kW} 1$ 台(水柱 $3,700 \mathrm{~mm}$, 風量 $72 \mathrm{~m}^{3} / \mathrm{min}$ ) にて利用側に送気しており, 布設パイ プは $14^{\prime \prime} ， 8^{\prime \prime} ， 6^{\prime \prime} ， 4^{\prime \prime}$ ガス拔管約 $11,300 \mathrm{~m}$ ，坑外注 $12^{\prime \prime} ， 8^{\prime \prime}$ 約 $1,880 \mathrm{~m}$ でありその系統は第 5 図に示す。 なお今後のガス抜量の増大にそなえて, 坑外に $175 \mathrm{~kW}$
ブロワー1台抒よび坑内パイプの増設を急い でいる。

\section{7. ガス誘導管理}

誘導ガスは流量, 濃度がそれぞれ異なり， とくに払通過時に预けるガス濃度の低下等が あるため，これら各孔，座及び各支流分岐に おける誘導負圧を適宜調節することにより， 坑外ブロワーにおける誘導ガスの濃度および 流量を安定したものにすることができる訳 で，当所では各個所婂けるこれらを測定記 録して随時調節を行なつている。

またこの他にガス拔個所全般につき $\mathrm{CO}$ 検知, 温度観 測を定期的に㧍こない自然発火の兆候を察知するこ上に している。

なおガス抜に関する一切の工事打よびガス拔パイプ布 設坑道における仕繰作業等については，特別の伺様式を 決めその管理，保全に万全を期している。

\section{8. 結一言}

当所に扔ける坑内ガス抜は漸くその端緒についたばか りであるが，とくに現在具体的に実施中の地山貫層穿孔 ガス拔については，座造りその他に相当の経費を要する が，採炭切羽とくに一次払の切羽へ涌出するガス量を大 幅に減少させ，その結果保安面また利用面において，さ らに今後の深部移行に伴ら企業合理化を可能ならしめる

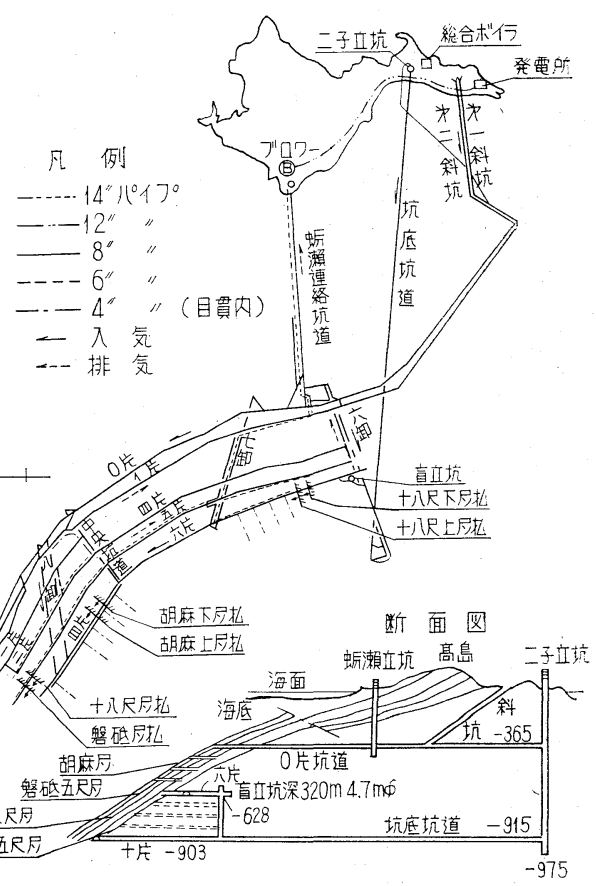

第5図 ガス拔系統図 
そいらことにより，その経費は十分償われているものと 信ずる。

今後当所としてはこの地山ガス抜をさらに強力に推進 していく必要があり,このため穿孔機および人員の増強 を急いでいる。な打穿孔機についても場所によりガス抜 穿孔長が増大するので，これ応じた穿孔を可能ならし める強力長孔穿孔機を導入して試験中である(HY-203)。

この他現在坑外に扔けるガス吸引濃度は $50 \%$ 前後であ るが，より以上の高濃度はそれだけすべてに有利である 訳で, 当所ではガス抜穿孔の口元ガイドパイプは坑内使
用済の 3 2in の古パイプを再利用中であるが，これと ても今後のガス抜増大に伴い限度があるわけで, これに 代わる口元パッカー, 軽便ガイドパイプ等につき検討中 であり，これとともにロ元セットの方法についてもアロ ン A -42 または CMCのような薬剤添加により,さら に高濃度ガスの誘導をテスト中である。

要はより完全なるガス抜は,より安全につながりかつ ガス利用面の搪大も期待できるので，今後ますます有効 なるガス抜計画を実施したいと念願しているわけで大方 の御指導を御願いしたい。

\section{赤平炭鉱の自然発火と対策 \\ Prevention of Spontaneous Combustion in Sumitomo Akabira Coal Mine}

UDC 622. $822: 33(524)$

中島重 治*

Shigeharu NAKAJIMA

\section{1. 緒言}

赤平炭鉱の自然発火掞よびその兆候は，昭和16年採炭 開始以来56回を数えているが，そのうち11回の爆発をと もなつている。したがつて，自然発火すなわち爆発とい ら状沉を常に考慮して処置を行なわなければならない。 そのため失われた炭量，資材等被害は実に大きいものが 㐫り，自然発火の消長は経営の成否を左右するといつて も過言でない。

開坑当初見受られた急傾斜払掠よび払跡に㧍ける自然 発火は，1）厚層採炭方式の改善 (上段先行スライシン グ方式の採用)，2）充填ズリの全クラッシャ化，3）完全 採掘の徹底，4）払内残炭の岩粉被覆の徹底，5）切羽進 行速度の上昇と早期密閉, などの対策実施により減少し

第 1 表 自然発火括よびその兆候の年別個 所別消火法別表

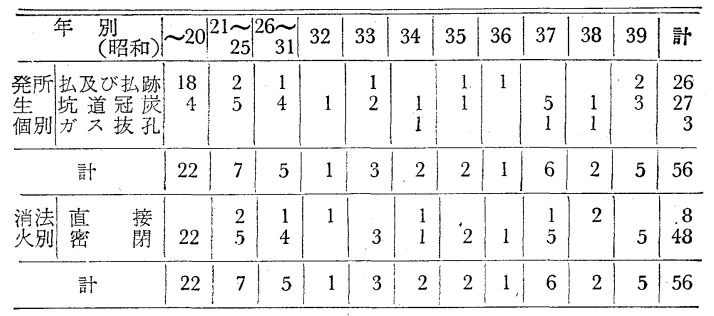

第2表 レベル別, 層別発生分布表

\begin{tabular}{|c|c|c|c|c|c|c|c|c|c|}
\hline & $11 \#$ 上 & $11 \#$ & $\begin{array}{l}11 \text { 击 } \\
\text { 中間 }\end{array}$ & $10 \#$ & $10 \#$ 下 & 9 & 8 & $7=$ & 訫 \\
\hline $\begin{array}{l}\sim 200 \mathrm{~L} \\
\sim \\
\sim \\
\sim 550 \mathrm{~L} \\
\sim 550 \mathrm{~L}\end{array}$ & 2 & $\begin{array}{l}4 \\
5 \\
9\end{array}$ & 1 & $\begin{array}{l}1 \\
1 \\
5\end{array}$ & $\begin{array}{l}1 \\
1 \\
2\end{array}$ & $\begin{array}{r}8 \\
-10 \\
8\end{array}$ & $\begin{array}{l}1 \\
2 \\
2\end{array}$ & $\begin{array}{l}2 \\
4\end{array}$ & $\begin{array}{l}18 \\
24 \\
14\end{array}$ \\
\hline 計 & 2 & 9 & 1 & 7 & 2 & 26 & 3 & 6 & 56 \\
\hline
\end{tabular}

注 一50L占少ないのは切羽数が少ないため

* 住友石炭鉱業株式会社赤平鉱業所 鉱務係曼
ている。この点については，昭和33年10月全炭技におい て発表し炭鉱技術 33 年 13 号に記載してめるので省略す る。

最近における自然発火およびその兆候のほとんどは坑 道・払の冠炭であり，まれにガス抜孔に関連があるとみ られる。以下その実例を報告し, 赤平炭鉱に打ける自然 発火效策を実技的な面から報告する次第である。第 1 表, 第 2 表は, 過去56例を発生個所, 消火法, レベル, 層別，年別に分類したものである。

\section{2. 赤平炭鉱における自然発火の兆候および 進行状態}

\section{1 自然発火の進行過程}

自然発火の進行状態は, 自然因と人工因の組合わせに より種々の形をとつて現われているが，大要次の現象の いずれかの組合わせをとつて進行している。

1) 温度の上昇，2）メタンの増加，3）湿度の増加, 4) 腐敗臭, 5) $\mathrm{CO}$ の発生, 6) $\mathrm{C}_{2} \mathrm{H}_{4}$ の発生, 7) $\mathrm{CO}_{2}$ の増加，8）甘酸臭 (石炭酸臭, アルコール臭)，9）油臭 (揮発油臭, 石油臭, タール臭)，10）木の燻る臭，11） 発煙発火, 以上諸現象中最近は臭気と $\mathrm{CO}$ の検知に依る 発見が多く，第 3 表発見現象別表にも示すように昭和 35 年以降16回中狊気, $\mathrm{CO}$ の検知で発見されたものが13回

第3 表 自然発火発見現象別表

\begin{tabular}{|c|c|c|c|c|c|c|c|c|c|c|c|c|}
\hline $\begin{array}{l}\text { 年 別 } \\
\text { (昭和) }\end{array}$ & $\sim 20$ & $\begin{array}{l}21 \\
2 \\
25\end{array}$ & $\begin{array}{c}26 \\
2 \\
31\end{array}$ & 32 & 33 & 34 & 35 & 36 & 37 & 38 & 39 & 計 \\
\hline 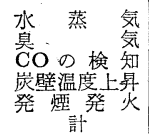 & $\begin{array}{r}1 \\
8 \\
5 \\
5 \\
8 \\
22\end{array} \mid$ & \begin{tabular}{l|}
1 \\
3 \\
2 \\
1 \\
7
\end{tabular} & $\begin{array}{l}3 \\
1 \\
1 \\
5\end{array}$ & $\begin{array}{l}1 \\
1\end{array}$ & 3 & $\begin{array}{l}1 \\
1 \\
2\end{array}$ & $\begin{array}{l}1 \\
1\end{array}$ & 1 & $\begin{array}{l}3 \\
2 \\
1 \\
\\
6\end{array}$ & $\begin{array}{l}1 \\
1 \\
2\end{array}$ & $\begin{array}{l}1 \\
3 \\
1 \\
5\end{array}$ & $\begin{array}{r}2 \\
23 \\
9 \\
11 \\
11 \\
56\end{array}$ \\
\hline
\end{tabular}

